\title{
Microhardness analysis of halite from different salt-bearing formations
}

\author{
Tomasz TOBOŁA ${ }^{1, *}$, Katarzyna CYRAN ${ }^{2}$ and Marek REMBIŚ ${ }^{1}$ \\ 1 AGH University of Science and Technology, Faculty of Geology, Geophysics and Environmental Protection, \\ al. A. Mickiewicza 30, 30-059 Kraków, Poland \\ 2 AGH University of Science and Technology, Faculty of Mining and Geoengineering, al. A. Mickiewicza 30, 30-059 Kraków, \\ Poland
}

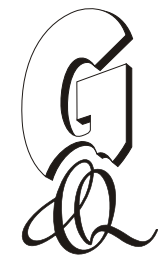

Toboła, T., Cyran, K., Rembiś, M., 2019. Microhardness analysis of halite from different salt-bearing formations. Geological Quarterly, 63 (4): 771-785, doi: 10.7306/gq.1499

Associate editor: Wojciech Drzewicki

\begin{abstract}
Microhardness tests were carried out on single halite crystals. They were conducted on the (001) surface, with the indenter set in two directions: parallel to the halite face (010); and parallel to the (110) face. The halite crystals represent salt formations of different ages (Devonian, Zechstein, Badenian), depths (from 1835.5 to $195 \mathrm{~m}$ ) and intensities of tectonic disturbance (horizontally stratified, salt dome, strongly folded). The measurement results revealed specific features of the halite crystals analysed. Firstly, the data obtained show microhardness anisotropy in halite crystals. Moreover, microhardness correlates with the depth of the salt-bearing formations. Halite crystals from deeper levels showed higher microhardness, though there was no correlation between the intensity of tectonic deformation and the average Vickers hardness (HV). The samples analysed show a variability of HV values and and of the shapes of imprints. These indicate zones where halite crystals are deformed at the atomic level and reflects the presence of defects in the crystal lattice. Such deformation is reflected in an irregularity of the strike of cleavage planes. Consequently, the analysis of imprint shapes is a useful method for the examination of ductile minerals and materials.
\end{abstract}

Key words: microhardness, halite, salt formation, crystal defects, dislocations, shape of imprint.

\section{INTRODUCTION}

Rock salt has been extensively studied over recent years as regards its unique mechanical properties. Due to these, rock salt is often considered for geotechnical and industrial applications e.g., storage caverns. In conventional laboratory tests, rock salt shows both brittle and ductile behaviour. It exhibits a brittle behaviour up to the elastic stress limit; when loading exceeds the elastic limits. plastic behaviour is shown via ductile deformation. Ductile rock salt behavior results from its crystalline structure, the internal structure of halite crystals, impurities content and distribution as well as the presence of fluid inclusions (e.g., Carter and Hansen, 1983; Fossum et al., 1993; Jeremic, 1994; Hunsche and Hampel, 1999; Schulze et al., 2001; Liang et al., 2012; Cyran et al., 2016). Moreover, rock salt contributes to the evolution of salt structures, affects, regional tectonics and lubricates deformation structures in sedimentary basins (Jackson and Hudec, 2017).

\footnotetext{
* Corresponding author, e-mail: tob@geol.agh.edu.pl
}

Received: January 7, 2019; accepted: September 16, 2019; first published online: December 11, 2019
Unlike most rock-forming minerals, halite shows noticeable rheological properties even at room temperature and has the ability to recrystallize, particularly in the presence of water (Carter and Hansen, 1983; Drury and Urai, 1990; Carter et al., 1993; Hunsche et al., 1996; Schléder and Urai, 2005, 2007; Desbois et al., 2012). The deformation of halite single crystals has been studied by many researchers, including Buerger (1930a, b, c), Christy (1956), Hadin and Hager (1958) and Shlichta (1968). It was observed that halite crystals deform by slip along crystallographic planes in two slip systems: the primary slip system is along the crystallographic plane (100) with secondary slip systems (110) and (111). Moreover, Carter and Heard (1970) and Davidge and Pratt (1964) noted that the primary slip system is favoured by lower stress and temperatures. The temperature dependence of the secondary slip systems is much higher.

The inner structure of halite undergoes deformation under stress in natural conditions. The resulting deformation results in defects of the crystal lattice. A deviation from cubic symmetry in halite crystals was indicated in blue halite (Zelek et al., 2008, 2014). Another result of defects in a crystal lattice is birefringence determined in blue halite crystals (Buerger, 1930a; Shlichta, 1968; Carter and Hansen, 1983; Sonnenfeld, 1995).

Indentation techniques (microhardness tests) has been widely used as a non-destructive method of assessing the mechanical properties of materials. Understanding why materials 


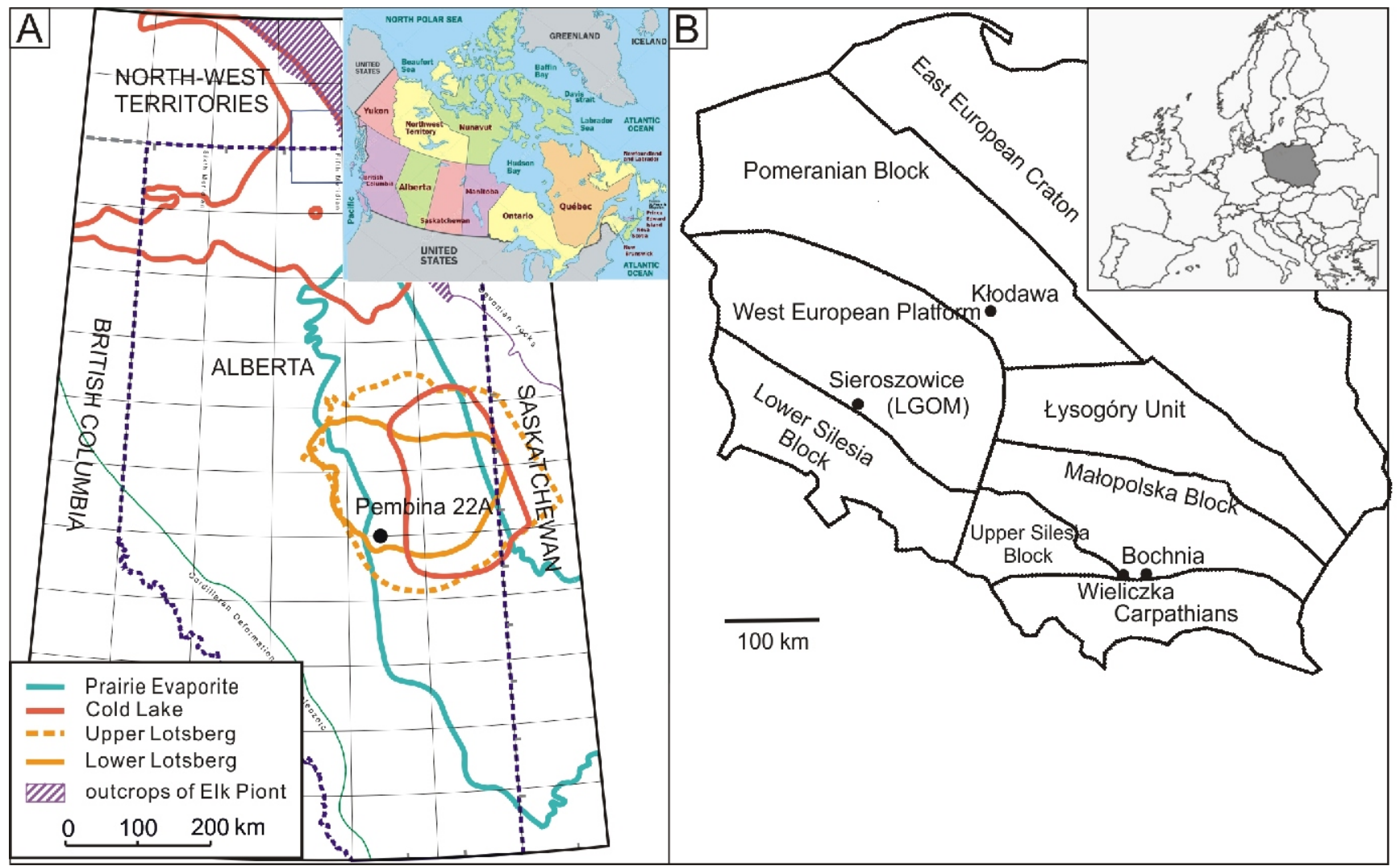

Fig. 1A - distribution of rock salt within the Devonian Elk Point Group in Alberta (Grobe, 2000); B - tectonic units in Poland with location of salt deposits

differ in hardness and indeed what hardness actually is, led to widespread adoption of indentation methods in the laboratory. In order to preserve geometrical similarity during an indentation, indenters in the shape of a four-sided diamond pyramid (the Vickers test) and three-sided pyramid (Berkovic test) were developed (Walley, 2012). In indentation tests of materials that exhibit rheological properties, plastic deformation must be considered along with elastic deformation (Atkinson et al., 2013). Consequently, halite in microhardness tests should be considered as elastic-plastic material.

The research described in this paper compares the microhardness of halite crystals from different salt-bearing formations. These salt-bearing formations occur at different depths, have distinct geological and tectonic histories and are built of halite crystals that underwent various conditions of stress and temperature. These conditions had an impact on the halite crystals, resulting in their deformation including the creation of lattice defects. These halite lattice defects should therefore be reflected in the results of microhardness tests. Furthermore, microhardness in halite crystals has so far been little studied (Brooks et al., 1975; Shakoor and Hume, 1981; Aptukov et al., 2010).

\section{MATERIALS}

Microhardness measurements were carried out on halite crystals collected from: the Lotsberg Salt Formation (Canada, Devonian); the Fore-Sudetic Monocline (Poland, Zechstein); the Kłodawa Salt Dome (Poland, Zechstein); and the Wieliczka and Bochnia Salt Mines (Poland, Badenian). The Lotsberg Salt Formation located in Alberta is the oldest salt formation in the Canadian area (Fig.1A). It belongs to the sedimentary rock se- quence known as the Elk Point Group (Wardlaw and Watson, 1966). It is underlain by the Basal Red Beds and overlain by the Ernesta Lake Formation. The Lotsberg Salt Formation lies horizontally, and is undisturbed by tectonics. It is subdivided into a lower and upper part, separated by a layer of red dolomitic shale. In both parts, the salt rocks are composed of coarsegrained halite with a small amount of dolomite and clay impurities (Kukiałka and Toboła, 2018). The halite crystals range in size from $\sim 1 \mathrm{~cm}$ to a few centimetres. The microhardness test sample was taken from the Pembina 22A borehole at depth $1835.5 \mathrm{~m}$.

The second sample analysed was taken from the Oldest Halite (Na1) occurring in the Lubin-Głogów Copper District (LGOM; Fig. 1B). The Oldest Halite is represented by halite crystals up to $15 \mathrm{~cm}$ in size which occur as veins or nests within the Na1 primary salts (Toboła and Markiewicz, 2009). The LGOM is part of the Fore-Sudetic Monocline and it is built of Permian and Triassic strata. The Permian unit is subdivided into terrestrial (Rotliegend) and marine (Zechstein) deposits. The Zechstein deposits are composed of four evaporite cyclothems but only the lowest cyclothem (PZ1) is fully developed and includes a rock salt layer (Na1) in the LGOM area (Kłapciński, 1964a,b, 1966, 1971; Szybist, 1976; Peryt, 1981). The salt layer (Na1) strikes WNW-ESE and dips at 3-8 (locally $15^{\circ}$ ) toward the NE. The internal structure of the salt layer is complicated with various types of folds, shear zones, flexures and fault zones that indicate large-scale salt movement (Banaszak et al., 2007; Burliga, 2007; Markiewicz, 2007; Toboła, 2014).

The third sample represents a "blue halite" (NatkaniecNowak and Toboła, 2003; Toboła et al., 2007; Toboła and Natkaniec-Nowak, 2008; Wesełucha-Birczyńska et al., 2008; Zelek et al., 2008, 2014; Toboła, 2016) while the fourth sample 
was taken from bituminous salts (Toboła, 2010; Wesełucha-Birczyńska and Toboła, 2016). Both types of salt occur in the Kłodawa Salt Dome (central Poland) in the form of veins or nests within almost all the Zechstein deposits (Fig. 1B). The Kłodawa Salt Dome is the largest salt structure in Poland. It belongs to the Izbica Kujawska-Łęczyca salt ridge (e.g., Werner et al., 1960; Wachowiak and Toboła, 2014; Toboła, 2016; Toboła and Wachowiak, 2018). The length of the dome is $\sim 26 \mathrm{~km}$ in the NW-SE direction and its width varies from 0.5 to $2 \mathrm{~km}$. The salt dome is built of rocks representing the fully developed Zechstein PZ2-PZ4 cyclothems composed of claystones, dolomites, anhydrites, rock salts and K-Mg salts. The lowest cyclothem PZ1 is known as tectonically transported blocks (Charysz, 1973; Burliga et al., 1995). All these deposits were highly disturbed by halotectonic and halokinetic processes during uplift of the dome.

The fifth and sixth samples were taken from the Wieliczka and Bochnia salt deposits respectively (Fig. 1B). These samples represent primary halite crystals from the brecciated part of the Wieliczka salt deposit and the Middle Salt member of the Bochnia salt deposit. Both salt deposits are located at the front of the Carpathian Thrust, within a narrow belt of folded Badenian strata, regarded as an allochthonous unit (e.g., Poborski and Skoczylas-Ciszewska, 1963; Ney et al., 1974; Garlicki, 1979). The development of this unit and of the Badenian salt deposits (Wieliczka, Bochnia) is closely connected with Carpathian orogenic movements. Therefore, the Wieliczka and Bochnia salt deposits are strongly elongated in an $\mathrm{E}-\mathrm{W}$ direction and narrow (up to $1 \mathrm{~km}$ ) in a N-S direction. The inner structure of these deposits is complicated due to strong folding (Poborski, 1952; Wiewórka, 1984; Cyran and Toboła, 2006, 2007).

\section{METHODS}

The microhardness tests were performed on the halite samples prepared as thick sections (plates). The thick plates were obtained by cutting the single halite crystals parallel to their cleavage. The dimensions of the thick plates were: thickness $\sim 3 \mathrm{~mm}$, length and width $\sim 2 \mathrm{~cm}$. Both surfaces of the thick sections were manually gently polished on felt with the addition of a diamond suspension. The quality of polished surfaces was controlled under a microscope in reflected light.

The resistance of the halite crystals to the stress exerted by external pressure acting on a point was measured as their microhardness $(\mathrm{HV})$. The indentation tests were conducted using a hardness tester Testlab HVKD-1000IS with a pyramidal diamond indenter (the Vickers method). In order to choose the optimal load, three force values were tested: $0.25 \mathrm{kgf}=0.245 \mathrm{~N}, 0.5 \mathrm{kgf}=$ $0.49 \mathrm{~N}, 1.0 \mathrm{kgf}=0.98 \mathrm{~N}$. The optimal load allowed observations of indentation marks under the microscope with a $40 \times$ objective. The value of $0.5 \mathrm{kgf}=0.49 \mathrm{~N}$ was chosen. Next, the chosen load was calibrated based on the microhardness standard (provided by the manufacturer). The microhardness was expressed as a quotient of the indenter load $(0.5 \mathrm{kgf}=0.49 \mathrm{~N}$, indenting time $=$ $10 \mathrm{sec}$.) and indentation depth calculating as a trigonometric relation from the lengths of the diagonals of the indentation marks (imprints). The indentation tests were performed in two versions. In the first version measurements were made in the areas parallel to the (100) and (010) faces of the halite crystal. In each area, measurements were performed along three lines that consist of 10 points. The lines were spaced at a distance of $1 \mathrm{~mm}$ from each other and the distance between indentation points in each line was also $1 \mathrm{~mm}$. Thereby, 30 microhardness values (HV) were obtained for each sample analysed and converted into $\mathrm{MPa}$. In the second version of the indentation test, measure-

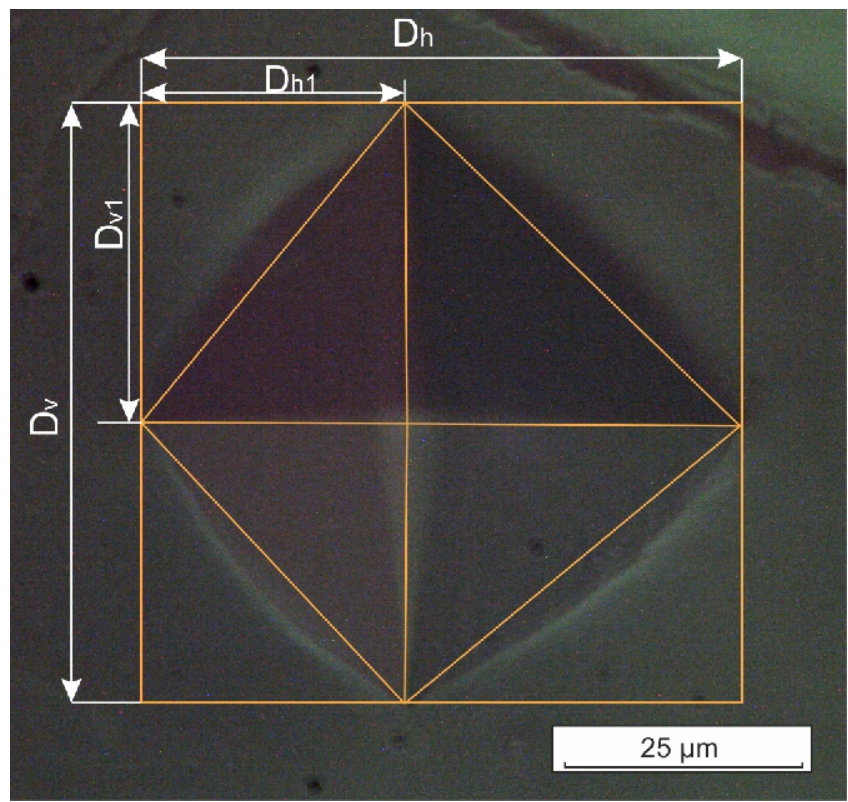

Fig. 2. Measurement methodology of a shift in the geometric centre of an imprint

ments were performed along two additional lines for three selected samples. Lines were arranged parallel to the (110) and $(11 ' 0)$ faces of the halite crystals. The lines and points were similarly spaced $1 \mathrm{~mm}$ apart, providing, an additional 20 microhardness $\left(\mathrm{HV}_{0.5}\right)$ values for each sample. All measurement results were used for calculating basic statistical parameters. Moreover, the shapes of the indentation marks (imprints) were analysed for all samples. Attention was paid to all distortions in the shape of an imprint, which were classified according to the description of Craig and Vaughan (1994). In order to check the irregularities observed in the indentation marks, the lengths of the diagonals and position of the geometric centre were analysed. The lengths of the two diagonals $\left(D_{h}, D_{v}\right.$ on Fig. 2$)$ recorded in the indentation tests were compared in each indentation mark for each sample analysed. The ratios between the two diagonals were calculated and shown on the graphs. The position of the geometric centre in each indentation mark and its shift in the horizontal and vertical direction was measured according to the methodology shown in Figure 2. The shift in a horizontal and vertical direction was calculated as ratios of $D_{h 1} / D_{h}$ and $D_{v 1} / D_{v}$, respectively. In this way, when there was no shift of a geometric centre, the ratio is 0.5 .

\section{RESULTS}

The results of the indentation tests are displayed as maps (Fig. 3), which show, with help of a colour scale, the range of measured $\mathrm{HV}$ in indentation points. As a result, there is no information about $\mathrm{HV}$ values in the area between these points. For this reason, in order to estimate HV values between indentation points, a Kriging method was applied. The Kriging method enables prediction of the value of a function at a given point by computing a weighted average based on the surrounding measured values.

The results of performed indentation tests indicated a large variability in average microhardness $(\mathrm{HV})$, as calculated for all samples analysed. A large variation in microhardness $(\mathrm{HV})$ value and its distribution within each thin section was noticed for most samples analysed. Moreover, the recorded in- 
A - sample no. 1 - Pembina 22A

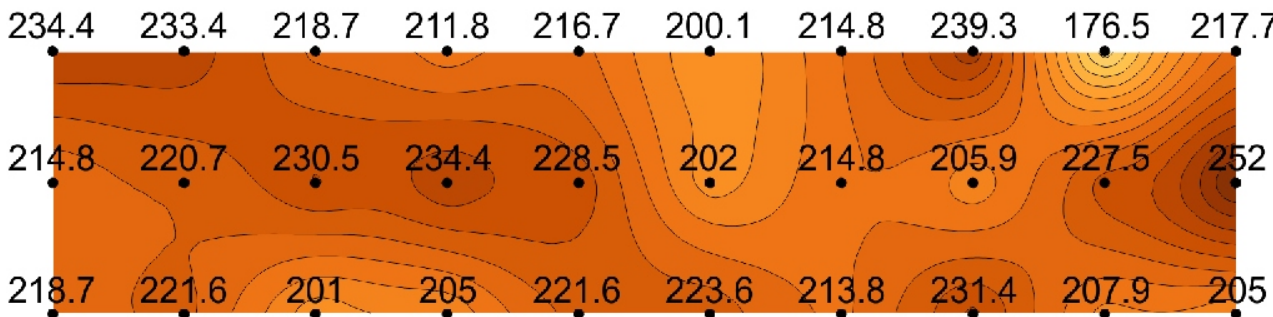

B - sample no. 2 - LGOM

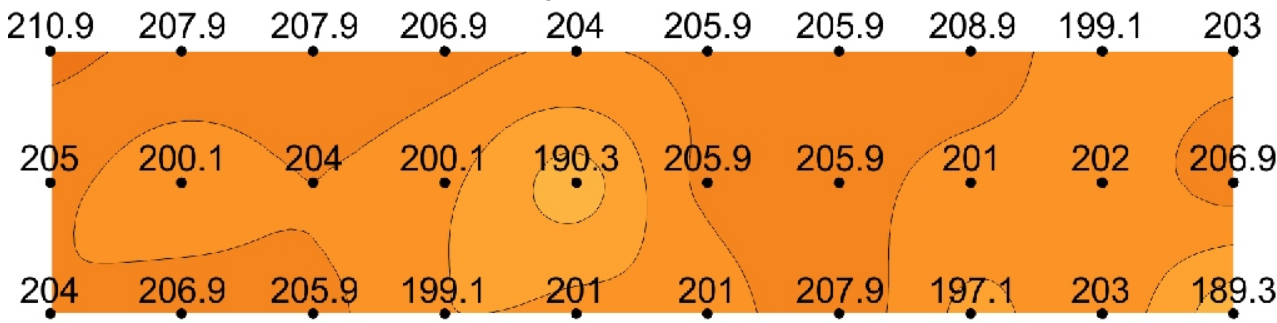

C - sample no. 3 - Kłodawa blue halite

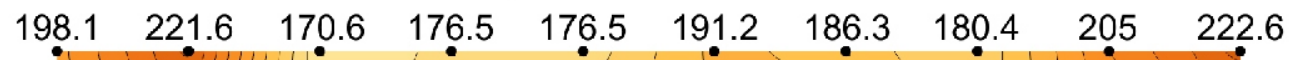

$\begin{array}{lllllllllll}194.2 & 197.1 & 172.6 & 192.2 & 191.2 & 186.3 & 202 & 185.4 & 198.1 & 189.3\end{array}$

$\begin{array}{llllllllll}198.1 & 206.9 & -212.8 & 191.2 & 187.3 & 189.3 & 177.5 & 184.4 & 204 & 190.3\end{array}$

D - sample no. 4 - Kłodawa bituminous salts

$\mathrm{MPa}$

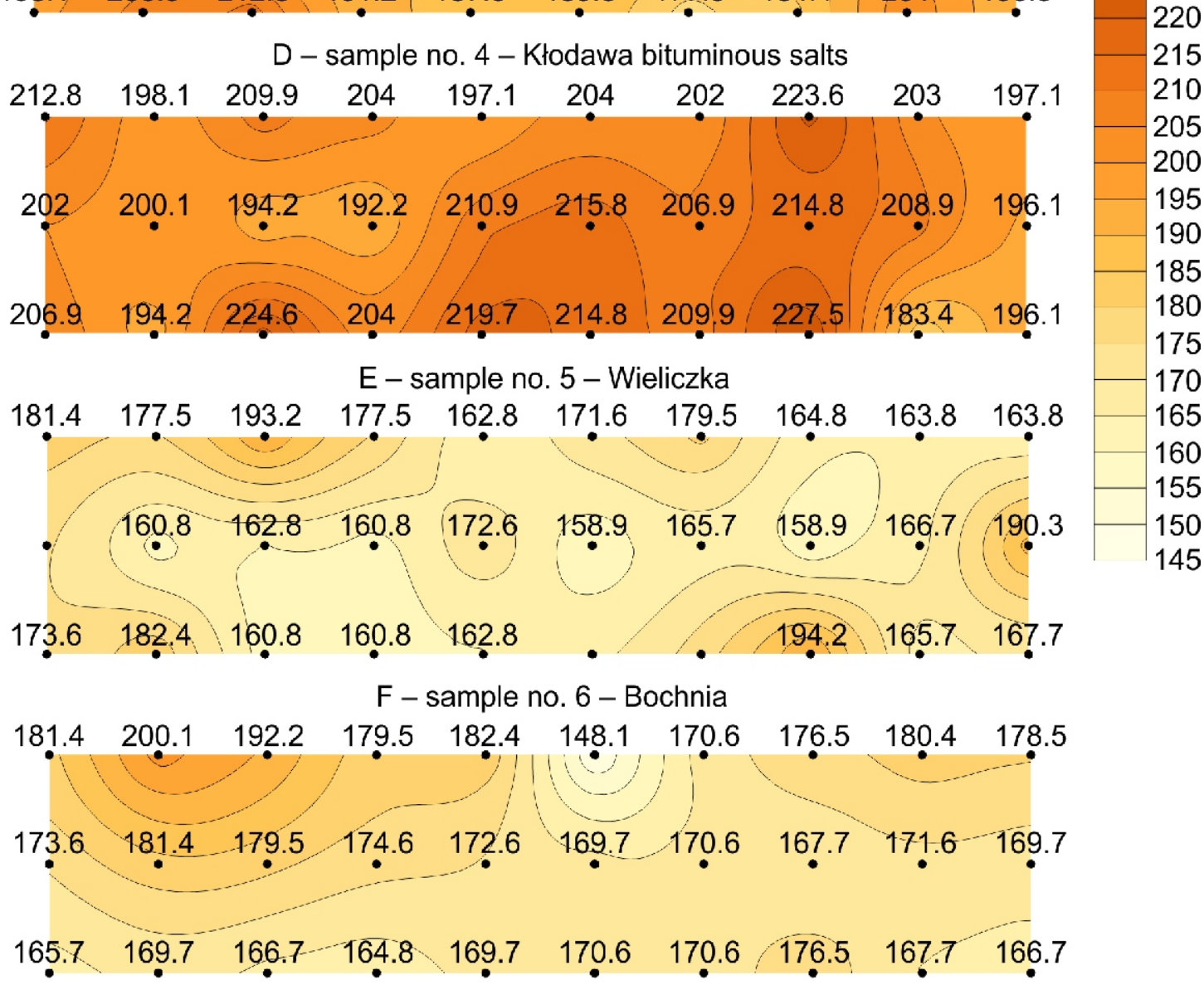

Fig. 3. Microhardness distribution within the samples (maps for the first version of the indentation test) 
HV values registered in the indentation test

\begin{tabular}{|c|c|c|c|c|c|c|c|c|c|}
\hline \multicolumn{7}{|c|}{ First test version } & \multicolumn{3}{|c|}{ Second test version } \\
\hline Sample no. & 1 & 2 & 3 & 4 & 5 & 6 & 2 & 4 & 6 \\
\hline Location & Pembina & LGOM & $\begin{array}{c}\text { Kłodawa } \\
\text { blue halite }\end{array}$ & $\begin{array}{c}\text { Kłodawa bi- } \\
\text { tuminous } \\
\text { salts }\end{array}$ & Wieliczka & Bochnia & LGOM & $\begin{array}{l}\text { Kłodawa bi- } \\
\text { tuminous } \\
\text { salts }\end{array}$ & Bochnia \\
\hline Depth [m] & 1835.5 & 950.0 & 630.0 & 720.0 & 135.0 & 195.0 & 950.0 & 720.0 & 195.0 \\
\hline $\begin{array}{c}\text { Indentation } \\
\text { point }\end{array}$ & & & & & V value $[\mathrm{MF}$ & & & & \\
\hline 1 & 234.4 & 210.9 & 198.1 & 212.8 & 181.4 & 181.4 & 188.3 & 192.2 & 163.8 \\
\hline 2 & 233.4 & 207.9 & 221.6 & 198.1 & 177.5 & 200.1 & 182.4 & 193.2 & 165.7 \\
\hline 3 & 218.7 & 207.9 & 170.6 & 209.9 & 193.2 & 192.2 & 182.4 & 195.2 & 163.8 \\
\hline 4 & 211.8 & 206.9 & 176.5 & 204.0 & 177.5 & 179.5 & 181.4 & 183.4 & 162.8 \\
\hline 5 & 216.7 & 204.0 & 176.5 & 197.1 & 162.8 & 182.4 & 183.4 & 200.1 & 161.8 \\
\hline 6 & 200.1 & 205.9 & 191.2 & 204.0 & 171.6 & 148.1 & 185.4 & 200.1 & 164.8 \\
\hline 7 & 214.8 & 205.9 & 186.3 & 202.0 & 179.5 & 170.6 & 182.4 & 196.1 & 163.8 \\
\hline 8 & 239.3 & 208.9 & 180.4 & 223.6 & 164.8 & 176.5 & 189.3 & 191.2 & 167.7 \\
\hline 9 & 176.5 & 199.1 & 205.0 & 203.0 & 163.8 & 180.4 & 186.3 & 187.3 & 160.8 \\
\hline 10 & 217.7 & 203.0 & 222.6 & 197.1 & 163.8 & 178.5 & 189.3 & 188.3 & 162.8 \\
\hline 11 & 214.8 & 205.0 & 194.2 & 202.0 & $247.1^{*}$ & 173.6 & 188.3 & 226.5 & 159.9 \\
\hline 12 & 220.7 & 200.1 & 197.1 & 200.1 & 160.8 & 181.4 & 188.3 & 211.8 & 161.8 \\
\hline 13 & 230.5 & 204.0 & 172.6 & 194.2 & 162.8 & 179.5 & 177.5 & 199.1 & 160.8 \\
\hline 14 & 234.4 & 200.1 & 192.2 & 192.2 & 160.8 & 174.6 & 183.4 & 189.3 & 161.8 \\
\hline 15 & 228.5 & 190.3 & 191.2 & 210.9 & 172.6 & 172.6 & 181.4 & 176.5 & 160.8 \\
\hline 16 & 202.0 & 205.9 & 186.3 & 215.8 & 158.9 & 169.7 & 179.5 & 182.4 & 165.7 \\
\hline 17 & 214.8 & 205.9 & 202.0 & 206.9 & 165.7 & 170.6 & 178.5 & 186.3 & 163.8 \\
\hline 18 & 205.9 & 201.0 & 185.4 & 214.8 & 158.9 & 167.7 & 183.4 & 187.3 & 173.6 \\
\hline 19 & 227.5 & 202.0 & 198.1 & 208.9 & 166.7 & 171.6 & 180.4 & 184.4 & 162.8 \\
\hline 20 & 252.0 & 206.9 & 189.3 & 196.1 & 190.3 & 169.7 & 185.4 & 188.3 & 160.8 \\
\hline 21 & 218.7 & 204.0 & 198.1 & 206.9 & 173.6 & 165.7 & & & \\
\hline 22 & 221.6 & 206.9 & 206.9 & 194.2 & 182.4 & 169.7 & & & \\
\hline 23 & 201.0 & 205.9 & 212.8 & 224.6 & 160.8 & 166.7 & & & \\
\hline 24 & 205.0 & 199.1 & 191.2 & 204.0 & 160.8 & 164.8 & & & \\
\hline 25 & 221.6 & 201.0 & 187.3 & 219.7 & 162.8 & 169.7 & & & \\
\hline 26 & 223.6 & 201.0 & 189.3 & 214.8 & 290.3* & 170.6 & & & \\
\hline 27 & 213.8 & 207.9 & 177.5 & 209.9 & $254.0^{*}$ & 170.6 & & & \\
\hline 28 & 231.4 & 197.1 & 184.4 & 227.5 & 194.2 & 176.5 & & & \\
\hline 29 & 207.9 & 203.0 & 204.0 & 183.4 & 165.7 & 167.7 & & & \\
\hline 30 & 205.0 & 189.3 & 190.3 & 196.1 & 167.7 & 166.7 & & & \\
\hline Average & 218.1 & 203.2 & 192.6 & 205.8 & 170.4 & 173.6 & 183.8 & 193.0 & 163.5 \\
\hline$x$ & \pm 5.59 & \pm 1.88 & \pm 4.94 & \pm 3.97 & \pm 4.20 & \pm 3.51 & \pm 1.69 & \pm 5.21 & \pm 1.45 \\
\hline $\mathrm{Me}$ & 218.2 & 204.0 & 191.2 & 204.0 & 165.7 & 171.1 & 183.4 & 190.3 & 162.8 \\
\hline$\sigma$ & 14.4 & 4.9 & 12.8 & 10.2 & 10.4 & 9.1 & 3.5 & 10.8 & 3.0 \\
\hline $\mathrm{CV}$ & 6.6 & 2.4 & 6.6 & 5.0 & 6.1 & 5.2 & 1.9 & 5.6 & 1.8 \\
\hline
\end{tabular}

* - rejected due to abnormally high values caused by the ingrowth of anhydrite crystals; $\mathrm{x}$ - measurement error determined by the Student-Fisher method; Me - median; $\sigma$-standard deviation; CV-coefficient of variation

dentation shapes (imprints) show some irregularities in all samples analysed.

In the first test version, the highest HV values from all samples analysed, both in indentation points and in the average value of $\mathrm{HV}$, were recorded in sample no. 1 from the Lotsberg $\mathrm{Fm}$. The values recorded in indentation points reached above 196.1 MPa with a maximum of 252.0 MPa (Table 1 and Fig. 3A), except for one point in which the HV value was 176.5 MPa. HV values recorded in indentation points that are shown in Figure $3 \mathrm{~A}$ show irregular zonal distribution within the sample (Fig. 3A). Areas characterized by high HV are sepa- rated by zones of low HV. Each zone consists of intervals represented by several points characterized by the same HV value (Fig. 3A). Areas of high HV are elongated in the left part of the map but in the right part there are two small areas divided by a low HV zone. Moreover, high variability in HV value is visible on the right side of the map (Fig. 3A).

The shapes of imprints in the halite from Pembina are the most irregular among all the samples analysed in the first test version. The imprints are elongated laterally (Figs. 4A-C and $5 A)$. The geometric center of the imprint is shifted laterally and slightly vertically (Fig. $4 \mathrm{~A}-\mathrm{C}$ ). The irregular shape of imprints is 


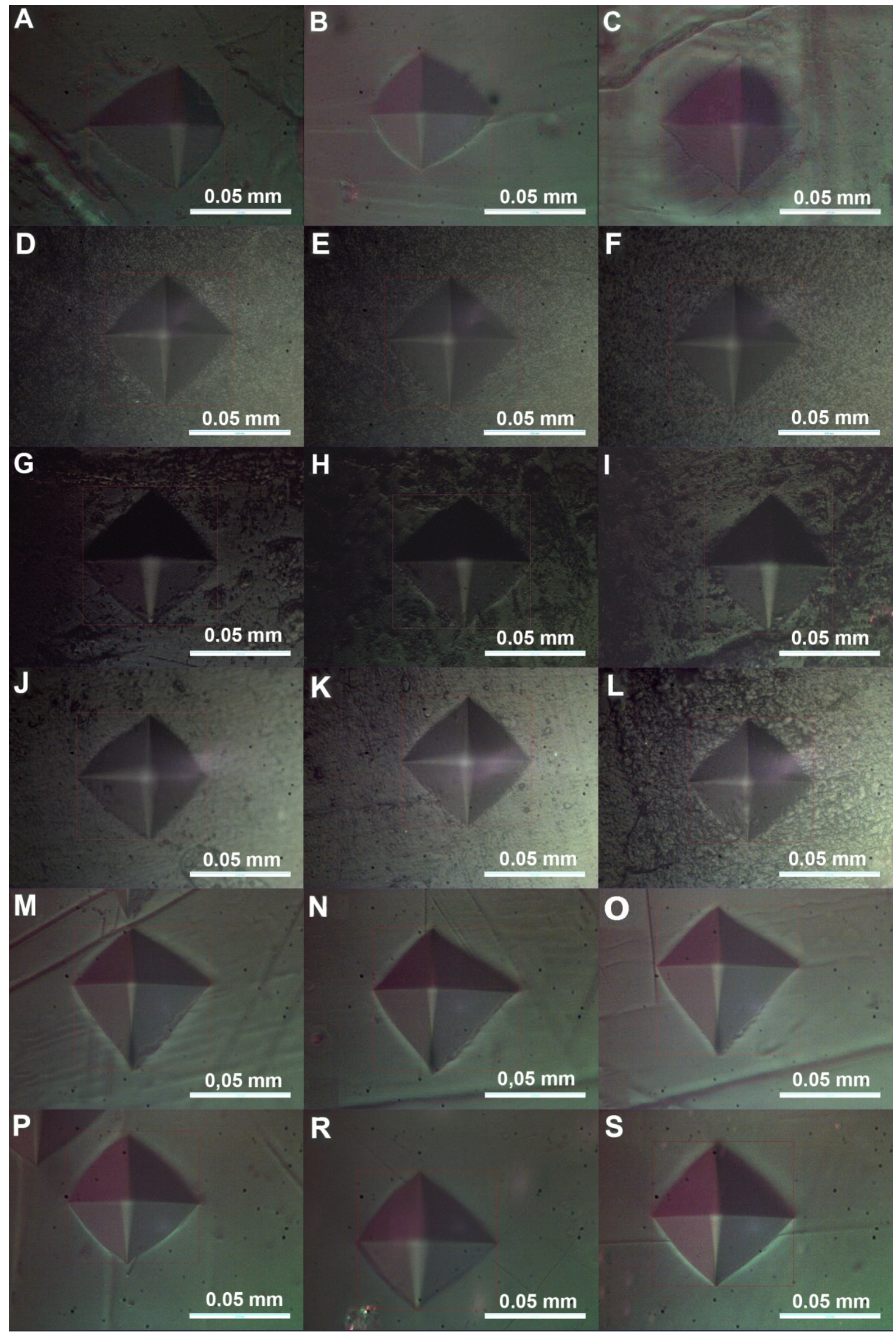

Fig. 4. The shapes of imprints registered in the first test version [parallel to the (100) and (010) faces] A-C - Pembina; D-F - LGOM, G-I - Kłodawa blue halite; J-L - Kłodawa bituminous salts; M-O - Wieliczka; P-S - Bochnia 

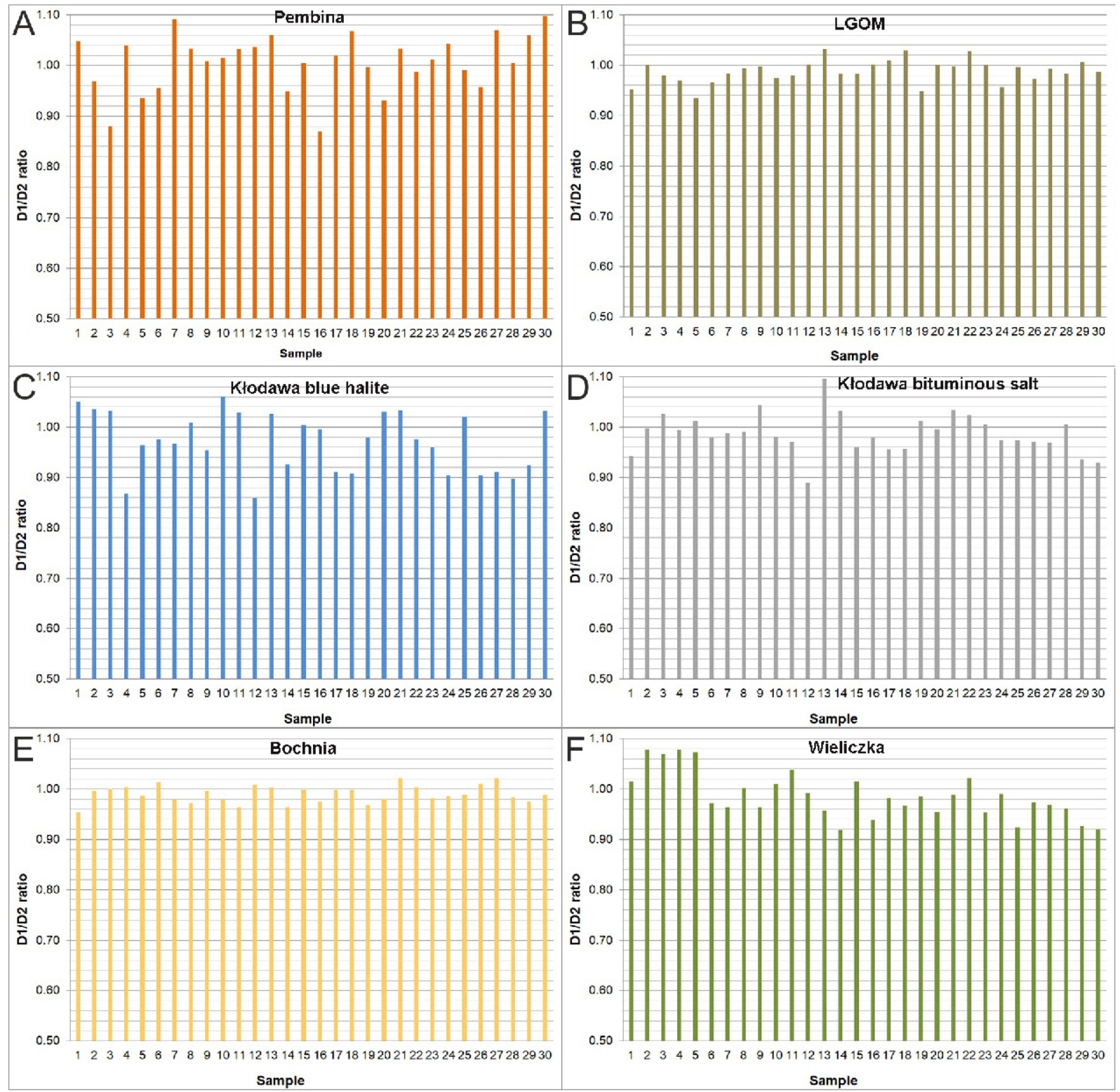

Fig. 5. The ratio between the length of diagonals recorded in the first test version

further indicated by the ratio between diagonals which varies from 0.86 to 1.10 (Fig. 6A). A convex shape of the imprint edges (Fig. 4A) prevails in the vast majority of indentation points, though, a few imprints are slightly sigmoidal (Fig. 4B,C). However, the point at which the HV value was the lowest showed a more regular shape (Fig. 4A).

High HV values were registered in sample no. 2 from the LGOM (Table 1 and Fig. 3B). The average HV recorded in this sample was $203.0 \mathrm{MPa}$. This sample is characterized by the lowest variability of $\mathrm{HV}$ values among all samples analysed. $\mathrm{HV}$ values registered in indentation points range from $189.3 \mathrm{MPa}$ to 210.9 MPa (Table 1). In the map, there are only four HV intervals arranged in several irregular zones (Fig. 3B). The intervals of the lowest $\mathrm{HV}$ values are located in the central area and in the right lower corner of the map. The zones distinguished by high HV comprise the top left and right parts of the map (Fig. 3B).

All indentation marks recorded in sample no. 2 are distinguished from other imprints analysed in the first test version by a regular shape (Fig. 4D-F). The ratio between diagonals is close to 1.0 in most cases (Fig. 5B). However, some irregularities in imprint shapes are visible. There is a slight lateral shift of the geometric centre (Fig. 6B) and the edges are slightly convex and sigmoidal (Fig. 4 E, F).

In the Kłodawa blue halite sample, zonation and large variability of HV values is clearly visible. The HV values measured at all indentation points are the range of 170.6 and $222.6 \mathrm{MPa}$ while the average $\mathrm{HV}$ reached a value of $192.2 \mathrm{MPa}$ (Table 1). There are two circular areas of high HV located in the right upper and left upper corners of the map (Fig. 3C). An elongated zone of the lowest $\mathrm{HV}$ is situated at the left side of the map near an area of higher HV values. Generally, the central area of the map is dominated by intervals of low HV. However, indentation points marked by high $\mathrm{HV}$ are grouped in the left and right parts of the map (Fig. 3C).

In blue halite from Kłodawa (sample no. 3) an irregular shape of the imprints dominates (Fig. 4G-I). The distortion of imprint shape is reflected by elongation in the lateral and vertical directions. This irregularity of imprint shape is reflected by 

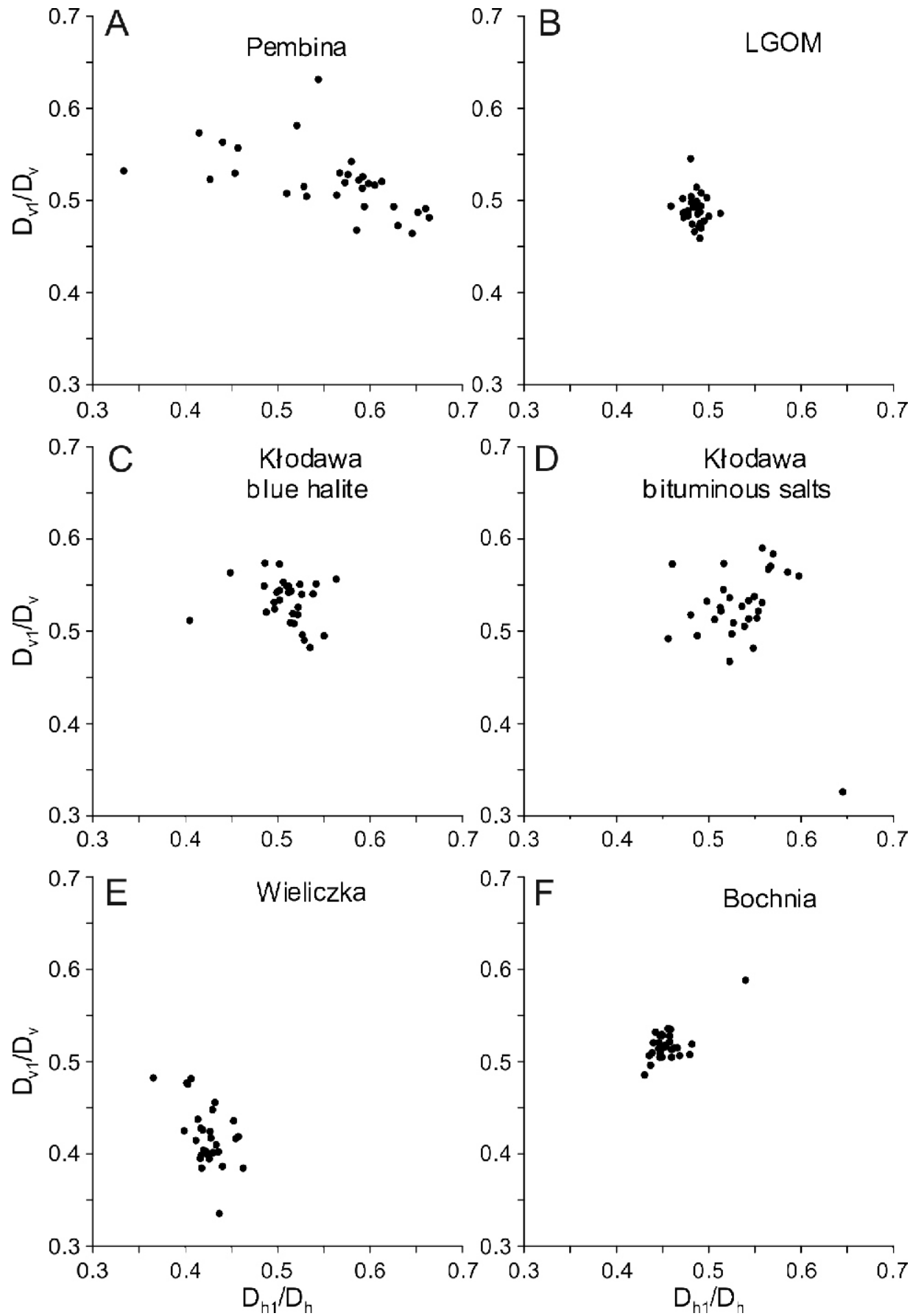

Fig. 6. Shifts in the geometric centre of imprints. Diagram for the first test version (parallel to the $(100)$ and $(010)$ faces)

the ratio between diagonals which varies from 0.86 to 1.08 (Fig. 5C) and by the shift of the geometric centre (Fig. 6C). The edges of imprints are very irregular, mostly convex (Fig. 4G, H) and slightly sigmoidal (Fig. 4I).

The microhardness characteristics of bituminous halite from Kłodawa (sample no. 4) are different from that described for the blue halite. The average HV of bituminous halite is like that calculated for the LGOM and reaches 205.80 MPa. However, HV values recorded in indentation points range from 183.4 to $227.5 \mathrm{MPa}$. This variety is reflected in the map (Fig. 3D) where several irregular zones marked by different HV intervals are visible. The zones of high HV are concentrated in the lower part of a map. The points at which the lowest HV were calculated are located in the bottom right and a left central areas of the map (Fig. 3D).

The shape of imprints in sample no. 4 are also very irregular. The edges of imprints recorded for bituminous halite are more irregular than the edges in blue halite (Fig. $4 \mathrm{~J}-\mathrm{L}$ ). The edges of imprints are characterized by sigmoidal and slightly convex shapes (Fig. $4 \mathrm{~J}-\mathrm{L}$ ). The irregular shape of an imprint is reflected by the ratio between diagonals that varies from 0.88 to 1.10 (Fig. 5D) and a shift of the geometric centre in both lateral and vertical directions (Fig. 6D).

The average HV calculated for sample no. 5 from Wieliczka is lower than values of other samples and amounts to 179.5 MPa. HV values measured in indentation points vary and 

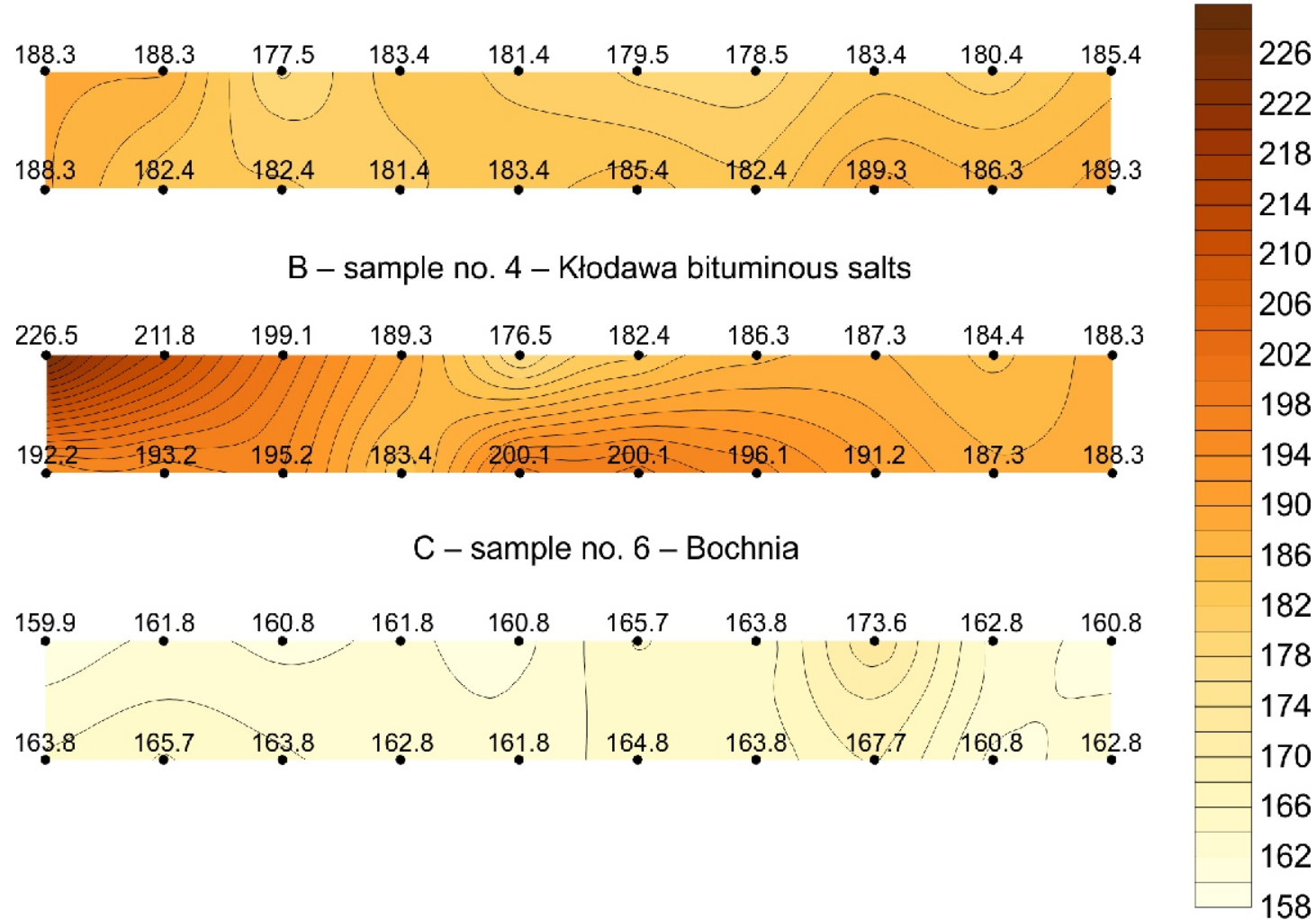

\section{B - sample no. 4 - Kłodawa bituminous salts}

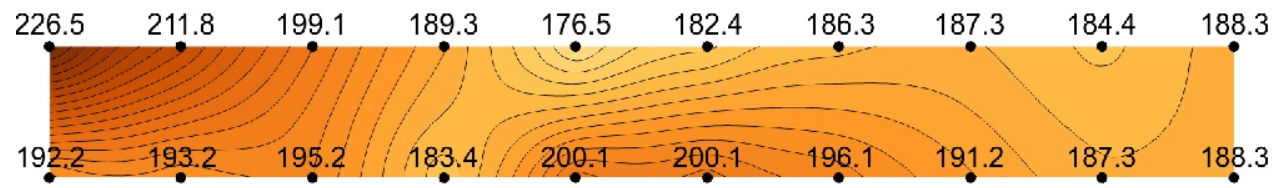

C - sample no. 6 - Bochnia

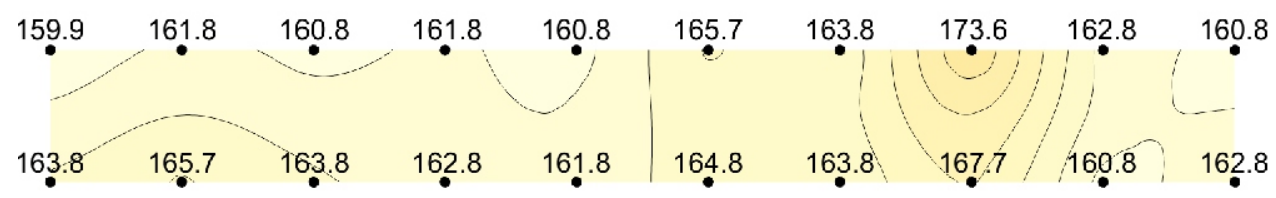

Fig. 7. Microhardness distribution within the samples (maps for the second version of the indentation test)

range from 158.9 to $194.2 \mathrm{MPa}$ (Fig. 3E). The distribution of HV intervals within the sample shown in the map is irregular but dominated by zones of low HV values. The intervals of the highest HV comprise three circular areas at the top, bottom and right side of the map. Consequently, intervals of low HV values fill the remaining space in the map (Fig. 3E).

The imprints in sample no. 5 are distinguished from other samples analysed in the first test version. The shape of imprints appears to be elongated in a vertical direction at first sight (Fig. 4M-O). However, distortion in the shape of imprints is caused primarily by a shift of the geometric centre (Fig. 6E). Additionally, the ratio between diagonals ranges from 0.92 to 1.08 (Fig. 5F). The edges of imprints are mostly sigmoidal, concave and more regular than in the samples from Kłodawa (Fig. 4M-O).

The lowest average HV was calculated for sample no. 6 from Bochnia (Table 1 and Fig. 4) and amounts to $173.6 \mathrm{MPa}$. Although the $\mathrm{HV}$ recorded in the indentation points ranges from 148.1 to $200.1 \mathrm{MPa}$, the great majority of HV values are below 176.5 MPa. This is reflected in the distribution of HV intervals within the sample shown in the map (Table 1 and Fig. 3F). There is only one area of high HV value visible, in the left top of the map. Low HV intervals are located in the central and right parts of the map (Fig. 3F).

The indentation shapes in sample no. 6 are more regular (Fig. 4P-S) than imprints from Kłodawa, Pembina and Wieliczka. The regular shape is reflected by the ratio between diagonals that is close to 1.0 (Fig. 5E). However, there are some irregularities in the edges of the imprints (Fig. 4P-S) as well as a slight shift of the geometric centre mostly in a lateral direction (Fig. 6F). A convex shape of edges dominates in most imprints.
In the second test version, features such as irregular distribution of HV intervals, high variability of HV values in indentation points and distortion of imprints were observed.

The average HV values calculated in the second test version are slightly lower than in the first test version for all samples analysed. Moreover, the range of HV values calculated in indentation points is narrower compared to the results from the first test version.

In the sample from the LGOM, the average HV recorded in the indentation points is $183.4 \mathrm{MPa}$. As in the first test version, the sample from the LGOM is characterized by the lowest variability of HV values among all samples analysed and ranges from 177.5 to $189.3 \mathrm{MPa}$ (Table 1 and Fig. $7 \mathrm{~A}$ ). In the map, the lowest HV intervals are located in two zones at the top of the map. However, irregular zones of high $\mathrm{HV}$ comprise the left side and right bottom of the map (Fig. 7A).

The shape of imprints in sample no. 7 is rather regular as in the first test version (Fig. $8 \mathrm{~A}-\mathrm{C}$ ). The regularity of an imprint is marked by a ratio between diagonals that is close to 1.0 (Fig. 9A). However, there are some slight distortions in the shape of edges that are slightly concave, with a slight shift of the geometric centre in a lateral and vertical direction (Fig. 10A).

The highest average HV (193.0 MPa) in the second test version was registered for bituminous halite from Kłodawa. HV values recorded in the indentation points comprise a wide variety of values from 176.5 to $226.5 \mathrm{MPa}$ (Fig. 7B). A map of HV registered in the indentation points shows several irregular zones marked by different HV intervals. The zones of high HV are located in the left part and at the bottom of the map (Fig. 7B). The points at which the lowest HV were recorded are grouped in the top central area of the map. 


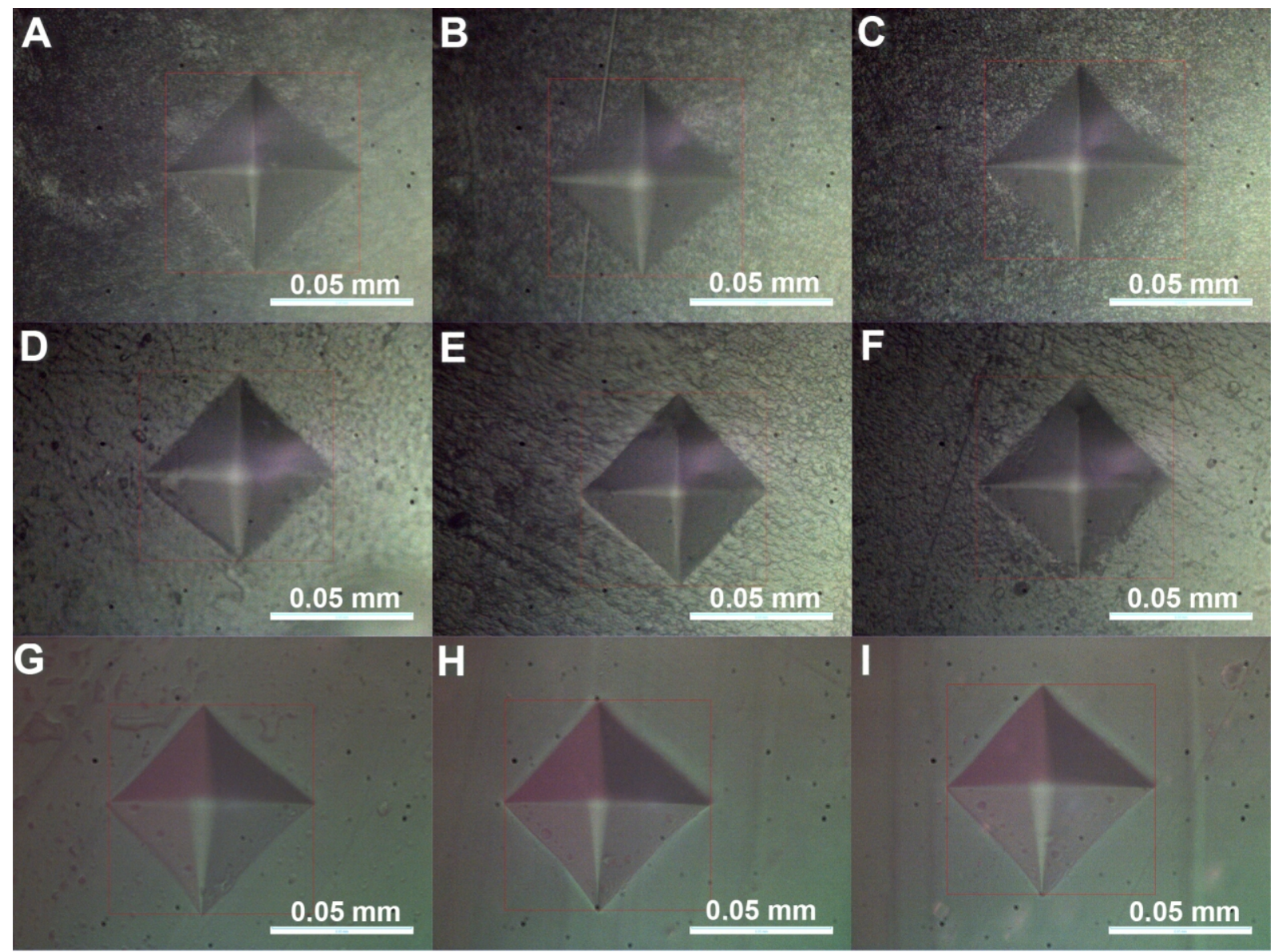

Fig. 8. The shape of imprints registered in the second test version (parallel to the (110) and (11'0) faces): A-CLGOM, D-F - bituminous salts, Kłodawa; G-I - Bochnia
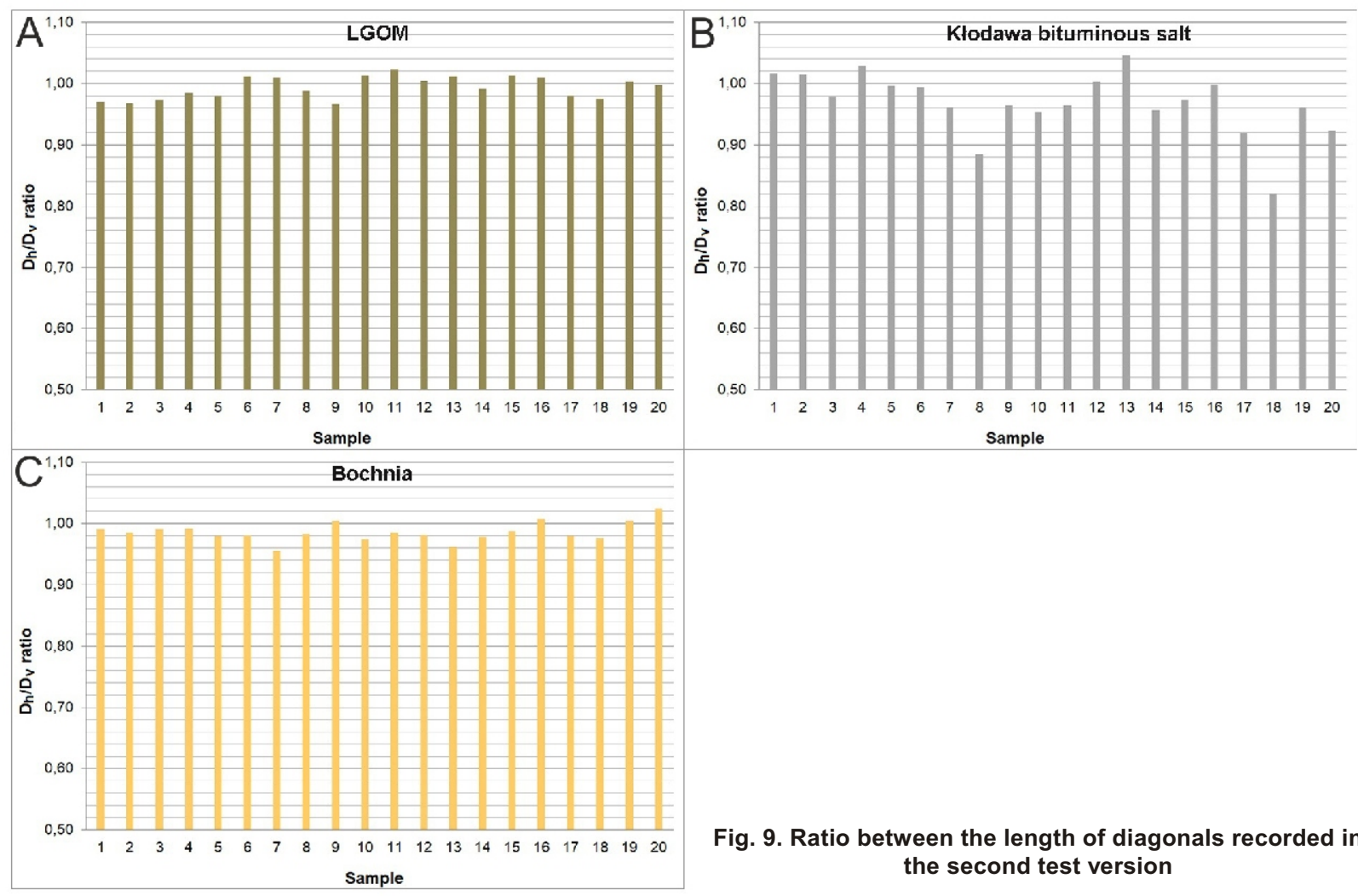

Fig. 9. Ratio between the length of diagonals recorded in the second test version 

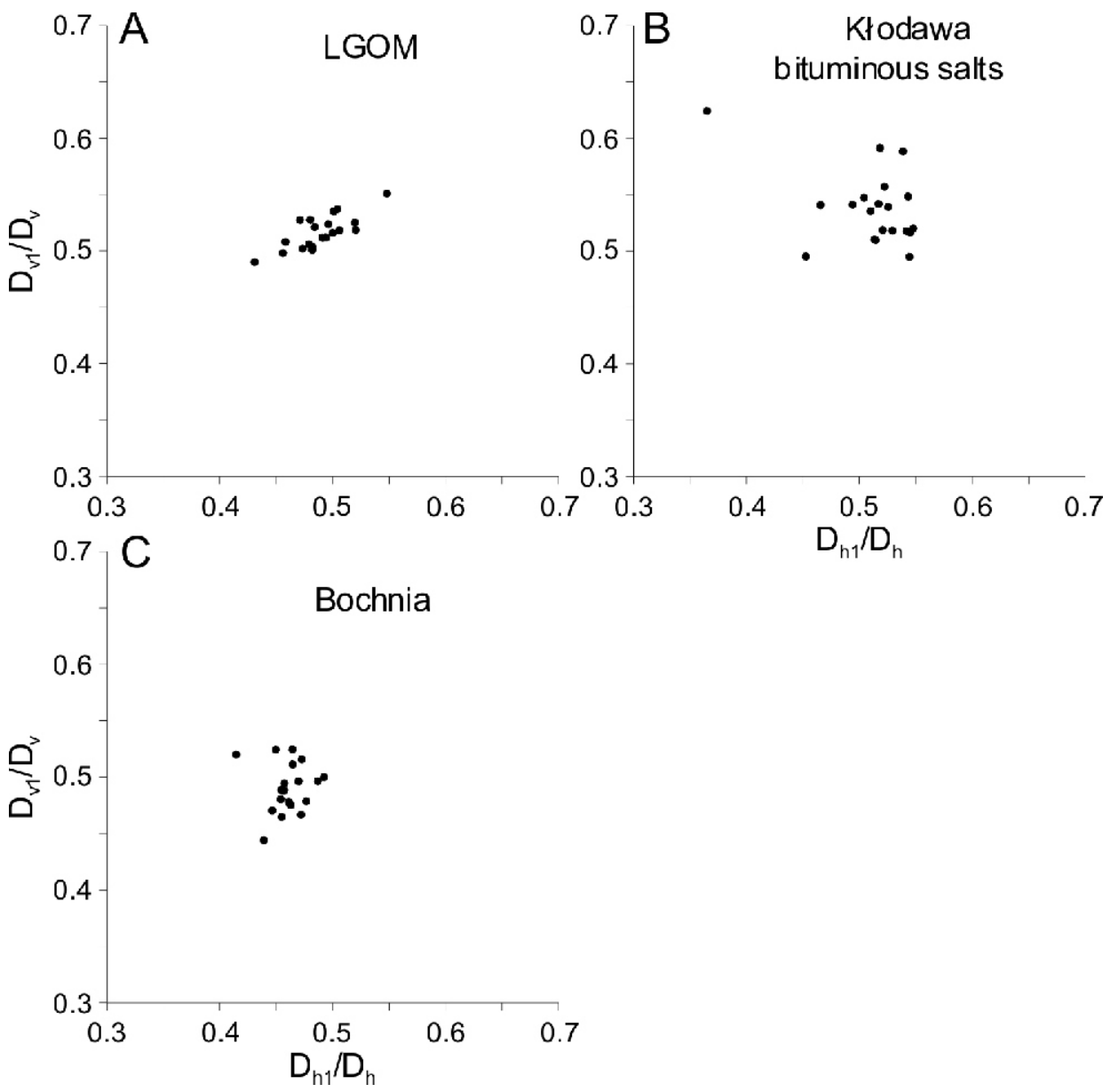

Fig. 10. Shifts in the geometric centre of imprints

Diagram for the second test version [parallel to the (100) and $\left(11^{\prime} 0\right)$ faces]

The shape of imprints in bituminous halite from Kłodawa is very irregular. The edges of imprints are sigmoidal and slightly concave (Fig. 8D, E). Moreover, the ratio between diagonals varies from 0.82 to 1.40 (Fig. 9B). The geometric centre of the imprints is slightly shifted in a lateral direction (Fig. 10B).

The lowest average HV in the second test version was determined for sample no. 9 from Bochnia (Table 1 and Fig. 7C) and amounts to $163.8 \mathrm{MPa}$. The HV recorded in the indentation points varies in a narrow range from 159.9 to $173.6 \mathrm{MPa}$. There is only one area of high HV value visible in the right top of the map, as in the first test version. Intervals of low HV comprise the central and left parts of the map (Fig. 7C).

The indentation shapes in the sample from Bochnia appears less regular than in the imprints from the LGOM because of the concave edges (Fig. 8F-H). However, there is only a slight shift of the geometric centre in a lateral direction (Fig. 10C) and the ratio between diagonals is close to 1.0 (Fig. 9C).

\section{DISCUSSION}

The samples analysed from different salt-bearing formations are characterized by high variability in average HV and a broad range of $\mathrm{HV}$ values recorded in the indentation points. This variability of $\mathrm{HV}$ values and $\mathrm{HV}$ distribution within each sample studied was greater in the first version of the indentation tests performed parallel to the (100) and (010) faces. Moreover, the average HV calculated for the measurements in this direction were higher than the average HV determined in the direction parallel to the $(110)$ and $\left(11^{\prime} 0\right)$ faces. This supports the hypothesis that the microhardness of these crystals is anisotropic and related to the direction of the specific crystallographic plane (Brookes et al., 1975; Craig and Vaughan, 1994; Stevenson et al., 2002).

The average HV calculated in all analysed samples correlates with the depth of salt-bearing formations related to these samples (Fig. 11). This correlation probably results from the lithostatic stress related to the weight of overburden rocks, the geothermal gradient and the rheological properties of halite (Peng and Zhang, 2007; Urai et al., 2008). Generally, all these processes are connected with the broadly recognized diagenesis and compaction of the deposits and they are well recognized in such rocks. However, changes in physical and mechanical properties in a single halite crystal in relation to the depth have not been considered so far. The correlation described above may result from halite's ability to recrystallize and undergo visco-plastic behaviour (Shlichta, 1968; Guillope and Poirier, 1979; Carter and Hansen, 1983; Roedder, 1984; Ter Heege et al., 2005) as well as to deformation of the crystal's internal structure under various stress and temperature conditions (Hansen and Carter, 1980). Nonetheless, the changes in stress and temperature with depth and their influence on the deposits are complex issues that cannot be considered linearly 


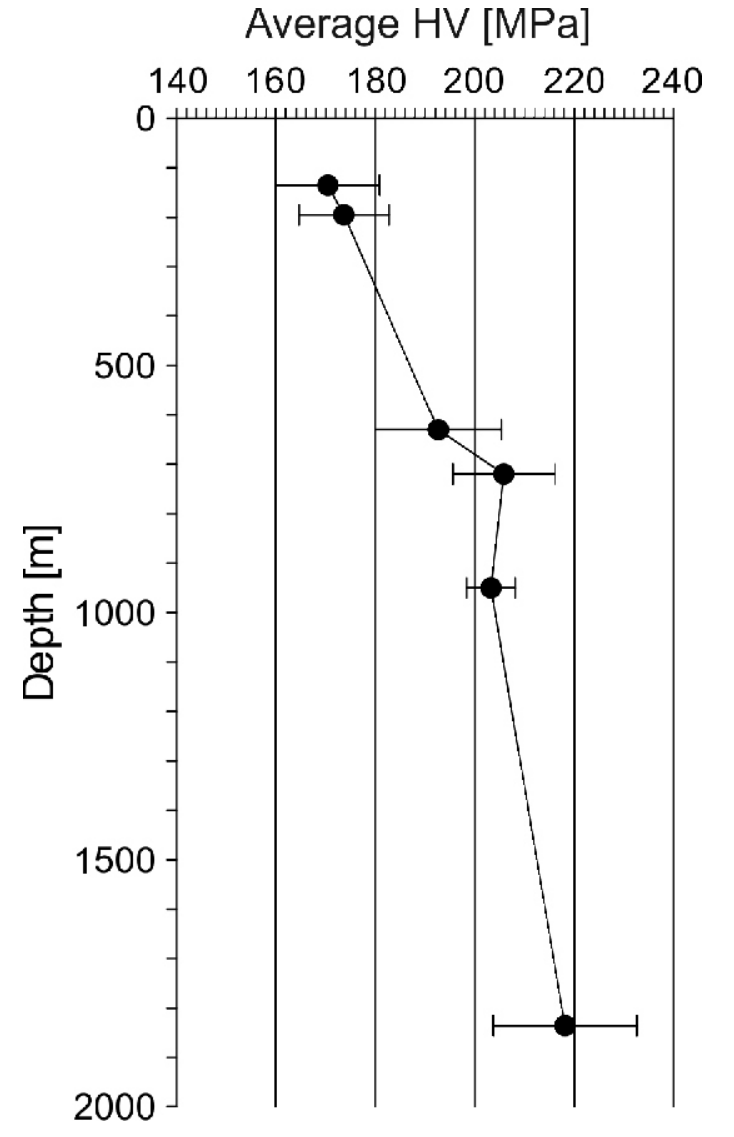

Fig. 11. Diagram of HV vs. depth of samples

(Pinińska, 2011). A deviation from cubic symmetry in halite crystals was indicated in blue halite samples by the use of single crystal X-ray diffraction methods (Zelek et al., 2008, 2014). Moreover, polarized light microscopy observations revealed optical anisotropy (birefringence) of blue halite crystals resulting from the crystals' deformation at the atomic level. The same optical features were found in halite from Devonian rock salt deposits (Pembina) and in bituminous salts from Kłodawa. Optical anisotropy (birefringence) recognized in crystals from Pembina and Kłodawa indicate the deformation of the halite internal structure. Consequently, it is possible that deformation of the halite crystals at the atomic level resulted in their higher microhardness. It should be emphasized that a correlation between average HV and the depth of salt-bearing deposits is not associated with tectonic disturbances. The geological conditions of the Pembina deposit which is part of the Lotsberg Salt Formation are not affected by tectonics. The Lotsberg Formation is located at the largest depth among all formations analysed but it is characterized by horizontal, undisturbed strata (Wardlaw and Watson, 1966; Kukiałka and Toboła, 2018). In contrast, the Badenian Salt Formation is strongly folded but the tectonic movements that had an impact on this formation took place at shallow depth (e.g., Poborski, 1952; Poborski and SkoczylasCiszewska, 1963; Ney et al., 1974; Garlicki, 1979; Wiewórka, 1984; Cyran and Toboła, 2006, 2007). In case of the Zechstein salt formation, halokinetic and halotectonic movements took place at a great depth that included burial of salt deposits.

$\mathrm{HV}$ values recorded in indentation points vary in a wide range for all samples analysed and similar HV values are distributed unequally within each sample studied. Areas distinguished by high HV are probably associated with a larger number of dislocations (structural imperfections in the crystal lattice) present in the natural crystals. Otherwise, zones of low HV are characterized by a lower number of dislocations which may result from partial recrystallisation. The presence of deformation and its influence on indentation properties has been described for many materials (Craig and Vaughan, 1994; Rabier et al., 2010).

Moreover, a variability of $\mathrm{HV}$ values is consistent with distortion in imprint shape. In halite from Pembina and Kłodawa, a large variability in HV values and their distribution within a sample is associated with irregular shapes of imprints. Otherwise, the samples from the LGOM are characterized by regular indentation shapes and low variability of HV values. Occurrence of distortion structures in the imprints analysed is probably affected by several factors: irregular shape of cleavage planes, susceptibility to plastic deformation and occurrence of dislocations. These dislocations are both natural and induced as a result of the indentation test (Craig and Vaughan, 1994; Stevenson et al., 2002). A convex shape of an imprint was mostly observed for samples from Pembina, the LGOM and Kłodawa that are characterised by high HV. The convex shape reflects piling up of material against the faces of the indenter due to the incompressibility associated with plastic deformation. It occurs when movement of dislocations is restrained by other internal defects and plastic strain concentrates near the indentation area (Giannakopoulos and Suresh, 1999; Zhang et al., 2011; N'jock et al., 2015). However, the concave shape reflects a sinking-in of materials around the indenter when the plastically deformed region is pushed out from the indenter with the imprint sinking below the initial surface level. Sinking-in occurs when dislocation movement is easy (Giannakopoulos and Suresh, 1999; Zhang et al., 2011; N'jock et al., 2015). A concave shape was observed mostly in the sample from Wieliczka and probably represents recrystallised halite from a boulder-rich part of the Wieliczka deposit.

Another analysed parameter was the shift of the imprints' geometric centre within each sample. A shift may indicate crystal deformation. However, a shift of imprint geometric centre may result from preparation of a thick plate. In this case, all values should differ equally from 0.5 (0.5 represents a regular shape in which a geometric centre is located in the middle of all sides) but there is no dispersion of these values. In the imprints analysed, a small dispersion of shift values was indicated in samples from the LGOM and Bochnia (Fig. 6B, F). In the diagram prepared for the sample from the LGOM (Fig. 6B) all points are grouped near a value of 0.5 . However, all points in the diagram prepared for the sample from Bochnia are concentrated in the area of low $\mathrm{H} 1 / \mathrm{H}$ ratio (left). This shift may indicate some roughness in the surface of the thick plate. In the second test version, the distribution of points in the diagram for Bochnia is similar to that in the first test version. The diagram for the LGOM shows a linear points distribution (Fig. 10A) that may indicate a zone with defects of crystal structure. The samples from Pembina, Kłodawa and Wieliczka are characterised by higher dispersion of shift values in the first test version (Fig. 6A, $\mathrm{C}-\mathrm{E})$. The highest dispersion was noted in the sample from Pembina and correlates with the highest HV values and a convex shape of imprints. Because thick plates were prepared by cutting the single halite crystals parallel to their cleavage, the shift of an imprint's geometric centre is caused by irregular strike (deformation) of cleavage planes. The irregular strike of the cleavage planes is probably associated with deformation of halite crystals caused by stress.

$\mathrm{HV}$ values recorded in indentation points during the indentation tests are higher that the results reported by Shakoor and Hume (1981) but lower than data provided for samples previously deformed by uniaxial compression (Aptukov et al. 2010). 
Consequently, HV values registered for the samples analysed are in the range between data reported in those papers. This may indicate deformation of the crystal structure resulting from natural conditions such as stress and temperature.

\section{CONCLUSIONS}

The results of indentation tests indicated several aspects of microhardness characteristics in halite crystals. Firstly, the HV values recorded at the indentation points differ depending on the measurement direction. Higher HV values were obtained for measurements parallel to the (100) and (010) faces of the halite crystal while HV values registered parallel to the (110) and $\left(11^{\prime} 0\right)$ faces were lower. These results demonstrate an anisotropy of halite microhardness. Moreover, in the first version of the indentation test [parallel to the (100) and (010) faces] a larger variability of $\mathrm{HV}$ values was noticed.

Secondly, analysis of the results revealed a correlation between the HV of halite and the depth of halite occurrence. The average $\mathrm{HV}$ of halite crystals that occur at great depth is higher than the average HV calculated for crystals located at shallow depth. However, there is no correlation between the intensity of of tectonic deformation and average HV.

Other aspects include a variability of HV values within the samples and the distortion of an imprint's shape. These aspects indicated zones where halite crystals are deformed at the atomic level and defects in the crystal lattice. Deformation of halite crystals is reflected by irregularity in the strike of the cleavage planes. Consequently, analysis of imprint shapes (distortion of shape, shift in the geometric centre, proportion of axes and diagonals) provides a useful method for examination of mechanical properties in ductile minerals and materials.

Acknowledgements. The authors would like to thank Dr. M. Schramm and an anonymous reviewer for valuable comments and suggestions which were very useful in preparation the final version of this paper. This work was financially supported by the AGH University of Science and Technology (Krakow, Poland), research projects No 16.16.140.315.

\section{REFERENCES}

Aptukov, V.N., Konstantinova, S.A., Skachkov, A.P., 2010 Micromechanical characteristics of karnalite, silvinite and rock salt at upper Kama deposit. Journal of Mining Science, 46 352-358.

Atkinson, C., Martínez-Esnaola, J.M., Elizalde, M.R., 2013. Contact mechanics: a review and some applications. Materials Science and Technology, 28: 1079-1091.

Banaszak, A., Garlicki, A., Markiewicz, A., 2007. Geology of the Oldest Rock Salt Kazimierzów in Sieroszowice I area (Polkowice-Sieroszowice Mine) (in Polish with English abstract). Przegląd Solny, Gospodarka Surowcami Mineralnymi PAN, 23, Spec. Issue, 1: 9-20.

Brookes, C.A., Burnard, R.P., Morgan, A., 1975. Anisotropy and indentation creep in crystals with the rock salt structure. Journal of Materials Science, Letters, 10: 2171-2173.

Buerger, M.J., 1930a. Translation-gliding in crystals. American Mineralogist, 15: 45-64.

Buerger, M.J., 1930b. Translation-gliding in crystals of the $\mathrm{NaCl}$ structural type. American Mineralogist, 15: 174-187.

Buerger M.J., 1930c. Translation-gliding in crystals of the $\mathrm{NaCl}$ type (concluded). American Mineralogist, 15: 226-238.

Burliga, S., 2007. Internal structure of subhorizontal bedded rock salt formation in the area of Sieroszowice, SW Poland - mesoand microstructural indication. Przegląd Solny, Gospodarka Surowcami Mineralnymi PAN, 23: 51-64.

Burliga, S., Kolonko, P., Misiek, G., Czapowski, G., 1995 Kłodawa salt mine. In: Upper Rotliegend - Zechstein: Terrestria - Marine Sedimentary Succession in Polish Permian Basin (ed J. Małecka): 45-54. XIII International Congress on Carboniferous-Permian, August 28 - September 2, 1995, Guide to Excursion A3, Kraków, Poland.

Carter, N.L., Hansen, F.D., 1983. Creep of rock salt. Tectonophysics, 92: 275-333.

Carter, N.L., Heard, H.L., 1970. Temperature and rate dependent deformation of halite. American Journal of Science, 269: 193-249.

Carter, N.L., Horseman, S.T., Russel, J.E., Handin, J.,1993. Rheology of rock salt. Journal of Structural Geology, 15: 1257-1271.

Charysz, W., 1973. Zechstein stage of Younger Salts (Z3) in Kujawy region (in Polish with English summary). Prace Geologiczne, 75: 1-68.
Christy, R.W., 1956. Creep of sodium chloride and sodium bromide at high temperature. Acta Metallurgica, 4: 441-443.

Craig, J.R., Vaughan, D.J., 1994. Ore microscopy and ore petrography. John Wiley and Sons. Inc, Second Edition.

Cyran, K., Toboła, T., 2006. Study of tectonic mesostructures in the Bochnia salt mine, South Poland (in Polish with English summary). Kwartalnik AGH Geologia, 32: 85-98.

Cyran, K., Toboła, T., 2007. The role of tectonics study for conservation and future development of miocene salt deposits (in Polish with English summary). Gospodarka Surowcami Mineralnymi PAN, 23: 143-156.

Cyran, K., Toboła, T., Kamiński, P., 2016. Effect of petrological features on mechanical properties of rock salt from the LGOM (Legnica-Głogów Copper District) (in Polish with English summary). Biuletyn Państwowego Instytutu Geologicznego, 466: $51-64$.

Davidge, R.W., Pratt, P.L., 1964. Plastic deformation and work-hardening in NaCl. Physica Status Solidi (b), 6: 759-776.

Desbois, G., Urai, J.L., De Bresser, J.H.P., 2012. Fluid distribution in grain boundaries of natural fine-grained rock salt deformed at low differential stress (Qom Kuh salt fountain, central Iran): implications for rheology and transport properties. Journal of Structural Geology, 43: 128-143.

Drury, M., Urai, J., 1990. Deformation-related recrystallization processes. Tectonophysics, 172: 235-253.

Fossum, A.F., Brodsky, N.S., Chan, K.S., 1993. Experimental evaluation of a constitutive model for inelastic flow and damage evolution in solids subjected to triaxial compression. International Journal of Rock Mechanics and Mining Sciences \& Geomechanics Abstracts, 30: 1341-1344.

Garlicki, A., 1979. Sedimentation of Miocene Salts in Poland (in Polish with English summary). Prace Geologiczne, 119.

Giannakopoulos, A.E., Suresh, S., 1999. Determination of elastoplastic properties by instrumented sharp indentation. Scripta Materialia, 40:1191-1198.

Grobe, M., 2000. Distribution and Thickness of Salt Within the Devonian Elk Point Group, Western Canada Sedimentary Basin. Alberta Energy and Utilities Board, Alberta Geological Survey, Earth Sciences Report 2000-02.

Guillope, M., Poirier, J.P., 1979. Dynamic recrystallization during creep of single-crystalline halite: an experimental study. Journal Geophysical Research, 84: 5557-5567. 
Handin, J.W., Hager, R.V. Jr., 1958. Experimental deformation of sedimentary rocks under confining pressure: tests at high temperature. AAPG Bulletin, 42: 2892-2934

Hansen, F.D., Carter, N.L., 1980. Creep of rock salt at elevated temperature. Proceedings of 21st U.S. Symposium on Rock Mechanics, May 27-30, 1980, Rolla, Missouri: 217-226.

Hunsche, U., Hampel, A., 1999. Rock salt - the mechanical properties of the host rock material for a radioactive waste repository. Engineering Geology, 52: 271-291.

Hunsche, U., Mingerzahn, G., Schulze, O., 1996. The influence of textural parameters and mineralogical composition on the creep behavior of rock salt. In: The Mechanical Behavior of Salt III, Proceedings of Third Conference, Palaiseau (France) 1993 (eds. M. Ghoreychi et al.): 143-151. Trans Tech Publications, Clausthal.

Jackson, P.M., Hudec, M.R., 2017. Salt Tectonics: Principles and Practice. Cambridge University Press, Cambridge.

Jeremic, M.L., 1994. Rock Mechanics in Salt Mining. CRC Press, Balkema Rotterdam.

Kłapciński J., 1964a. Stratigraphy of the Zechstein in the areas of Lubin, Sieroszowice and Wschowa (in Polish with English summary). Rocznik Polskiego Towarzystwa Geologicznego, 34: 65-93.

Kłapciński, J., 1964b. Paleogeographical characteristics of the Zechstein of the Fore-Sudetic Monocline (in Polish with English summary). Rocznik Polskiego Towarzystwa Geologicznego, 34: 551-577.

Kłapciński, J., 1966. Stratigraphy of the Werra-Anhydrites in the region of Lubin and Sieroszowice (Lower Silesia) (in Polish with English summary). Rocznik Polskiego Towarzystwa Geologicznego, 36: 65-78.

Kłapciński, J., 1971. Lithology, fauna, stratigraphy and paleogeography of the Permian in the Fore-Sudetic Monocline (in Polish with English summary). Geolgia Sudetica, 5: 77-135.

Kukiałka, P., Toboła, T., 2018. Petrological and geochemical characteristic of Lotsberg Salt Formation in Central Alberta (Canada) (in Polish with English summary). Przeglad Solny, Rocznik Polskiego Stowarzyszenia Górnictwa Solnego, 14: 77-87.

Liang, W., Zhang, C., Gao, H., Yang, X., Xu, S., Zhao, Y., 2012. Experiments on mechanical properties of salt rocks under cycling loading. Journal of Rock Mechanics and Geotechnical Engineering, 4: 54-61.

Markiewcz, A., 2007. Thin-skinned structure of the south of Foresudetic Monocline vs. management of Na1 salt (in Polish with English abstract). Przegląd Solny, Gospodarka Surowcami Mineralnymi PAN, 23, Spec. Issue, 1: 35-49.

Natkaniec-Nowak, L., Toboła, T., 2003. Blue Salt from kłodawa (Kujawy, Poland) (in Polish with English summary). Przegląd Geologiczny, 51: 435-438

Ney, R., Burzewski, W., Bachleda, T., Górecki, W., Jakóbczak, K., Słupczyński, K., 1974. Outline of paleogeography and evolution of lithology and facies of Miocene layers on the Carpathian Foredeep (in Polish with English summary). Prace Geologiczne, 82.

N'jock, M.Y., Chicot, D., Ndjaka, J.M., Lesage, J., Decoopman, X., Roudet, F., Mejias, A., 2015. A criterion to identify sinking-in and piling-up indentation of materials. International Journal of Mechanical Sciences, 90: 145-150.

Peng, S., Zhang, J., 2007. Engineering geology for underground rocks. Springer-Verlag, Berlin Heidelberg.

Peryt, T.M., 1981. Zechstein in the neighbourhood of the Fore-Sudetic Block (in Polish with English summary). Kwartalnik Geologiczny, 25 (1): 75-91.

Pinińska, J., 2011. The reliability of evaluation of elastic properties of rocks at great depths. Biuletyn Państwowego Instytutu Geologicznego, 446: 149-156.

Poborski, J., 1952. Złoże solne Bochni na tle geologicznym okolicy (in Polish). Biuletyn Instytutu Geologicznego, 78.

Poborski, J, Skoczylas-Ciszewska, K., 1963. Tektogeneza mioceńskich złóż soli na Podkarpaciu Zachodnim. Sprawozdania z Posiedzeń Komisji Naukowych PAN, Oddział w Krakowie, Lipiec-Grudzień 1963: 528-530.
Rabier, J. , Pizzagalli, L., Demenet, J.L., 2010. Dislocations in Silicon at High Stress. In: Dislocations in Solids (eds. J.P. Hirth and L. Kubin): 47-108. The Netherlands.

Roedder, E., 1984. Fluid inclusions. Mineralogical Society of America, 12.

Schléder, Z., Urai, J., 2005. Microstructural evolution of deformation-modified primary halite from Hengelo, the Netherlands. International Journal of Earth Sciences, 94: 941-956.

Schléder, Z., Urai, J., 2007. Deformation and recrystallization mechanisms in mylonitic shear zones in naturally deformed extrusive Eocene-Oligocene rocksalt from Eyvanekey plateau and Garmsar hills (central Iran). Journal of Structural Geology, 29 241-255.

Schultze, O., Popp, T., Kern, H., 2001. Development of damage and permeability in deforming rock salt. Engineering Geology, 61: 163-180.

Shakoor, A., Hume, H.R., 1981. Mechanical properties. National Bureau of Standards Monograph, 167: 104-203.

Shlichta, P.J., 1968. Growth, deformation, and defect structure of salt crystals. GSA, Special Papers, 88: 597-617.

Sonnenfeld, P., 1995. The color of rock salt - a review. Sedimentary Geology, 94: 267-276.

Stevenson, M.E., Kaji, M., Bradt, R.C., 2002. Microhardness anisotropy and the indentation size effect on the basal plane of single crystal haematite. Journal of the European Ceramic Society, 22: 1137-1148.

Szybist, A., 1976. Rock salt deposit in the Legnica-Głogów Copper Basin (in Polish with English summary). Przegląd Geologiczny, 24: 572-576.

Ter Heege, J.H., De Bresser, J.H.P., Spiers, C.J., 2005. Dynamic recrystallisation of wet synthetic polycystalline halite: dependence of grain size distribution on flow stress, temperature and strain. Tectonophysics, 396: 35-57.

Toboła, T., 2010. Inclusions in bituminous salts from Kłodawa Salt Dome (in Polish with English summary). Kwartalnik AGH Geologia, 36: 345-365.

Toboła, T., 2014. The influence of tectonics on petrological characteristics of anhydrite and anhydrite-halite intercalations in the Oldest Halite (Na1) (Zechstein, Upper Permian) of the Bądzów area (SW Poland). Geological Quarterly, 58 (3): 531-542.

Toboła, T., 2016. Inclusions in anhydrite crystals from blue halite veins in the Kłodawa Salt Dome (Zechstein, Poland). Geological Quarterly, 60 (3): 572-585.

Toboła, T., Markiewicz, A., 2009. Fluid inclusions in the Oldest Halite (Na1) in Głogów area (SW Poland) - preliminary results (in Polish with English summary). Kwartalnik AGH Geologia, 35 349-371.

Toboła, T., Natkaniec-Nowak, L., ed., 2008. Blue Halite of the Kłodawa Salt Dome (in Polish with English summary). Uczelniane Wydawnictwo Naukowo-Dydaktyczne AGH.

Toboła, T., Wachowiak, J., 2018. Evidence of high-temperature rock salt transformations in the areas of occurrence of borate minerals (Zechstein, Kłodawa salt dome, Poland). Geological Quarterly, 62 (1): 134-145

Toboła, T., Natkaniec-Nowak, L., Szybist, A., Misiek, G., Janiów, S., 2007. Blue Salts in Kłodawa Salt Mine (in Polish with English summary). Gospodarka Surowcami Mineralnymi PAN, 23, zeszyt spec., 1: 117-132

Urai, J.L., Schléder, Z., Spiers, C.J., Kukla, P.A., 2008. Flow and transport properties of salt rocks. Dynamics of Complex Intracontinental Basins: The Central European Basin SystemIn (eds. R. Littke, U. Bayer, D. Gajewski and S. Nelskamp). Springer, Berlin.

Wesełucha-Birczyńska, A., Toboła, T., 2016. Hydrocarbon alteration in the bituminous salt of the Kłodawa Salt Dome (Central Poland). Marine and Petroleum Geology, 75: 325-340.

Wesełucha-Birczyńska, A., Toboła, T., Natkaniec-Nowak, L., 2008. Raman microscopy of inclusions in blue halites. Vibrational Spectroscopy, 48: 302-307.

Wachowiak, J., Toboła, T., 2014. Phase transitions in the borate minerals from the Kłodawa salt dome (central Poland) as indica- 
tors of temperature processes in salt diapirs. Geological Quarterly, 58 (3): 543-554.

Walley, S.W., 2012. Historical origins of indentation hardness testing. Materials Science and Technology, 28: 1028-1044.

Wardlaw, N.C., Watson, D.W., 1966. Middle Devonian Salt Formations and Their Bromide Content, Elk Point Area, Alberta. Canadian Journal of Earth Sciences, 3: 263-278.

Werner, Z., Poborski, J., Orska, J., Bąkowski, J., 1960. A geological and mining outline of the Kłodawa salt deposit (in Polish with English summary). Prace Instytutu Geologicznego, 30 467-512.

Wiewiórka. J., 1984. Geologia wielickiego złoża solnego (in Polish). In: Wieliczka - skarb solny (ed. M. Broniowska): 18-20. Krajowa Agencja Wydawnicza, Warszawa.
Zelek, S., Stadnicka, K., Szklarzewicz, J., Natkaniec-Nowak, L., Toboła, T., 2008. Halite from Kłodawa: the attempt of correlation between lattice deformation and spectroscopic properties in UV-VIS (in Polish with English summary). Gospodarka Surowcami Mineralnymi PAN, 32: 159-172.

Zelek, S., Stadnicka, K., Toboła, T., Natkaniec-Nowak, L., 2014 Lattice deformation of blue halite from Zechstein evaporite basin: Kłodawa Salt Mine, Central Poland. Mineralogy and Petrology, 108: 619-631.

Zhang, P., Li, S.X., Zhang, Z.F., 2011. General relationship between strength and hardness. Materials Science and Engineering A, 529: 62-73. 